This is an electronic reprint of the original article. This reprint may differ from the original in pagination and typographic detail.

Author(s): Nokkala, Terhi

Title: Institutional Autonomy and the Attractiveness of the European Higher Education Area - Facts or Tokenistic Discourse?

Year: $\quad 2012$

Version:

Please cite the original version:

Nokkala, T. (2012). Institutional Autonomy and the Attractiveness of the European Higher Education Area - Facts or Tokenistic Discourse?. In C. A., S. P., V. L., \& W. L. (Eds.), European Higher Education at the Crossroads: Between the Bologna Process and National Reforms. Volume 1: Bologna Process Principles, Teaching and Learning, Quality Assurance, Mobility. (pp. 59-82). Springer. https://doi.org/10.1007/978-94007-3937-6_4

All material supplied via JYX is protected by copyright and other intellectual property rights, and duplication or sale of all or part of any of the repository collections is not permitted, except that material may be duplicated by you for your research use or educational purposes in electronic or print form. You must obtain permission for any other use. Electronic or print copies may not be offered, whether for sale or otherwise to anyone who is not an authorised user. 
To be published in:

Curaj, A.; Scott, P.; Vlasceanu, L.; Wilson, L. (Eds.) (2012). European Higher Education at the Crossroads. Between the Bologna Process and National Reforms. Dordrecht: Springer.

\title{
1. Institutional autonomy and the attractiveness of the European Higher Education Area - facts or tokenistic discourse?
}

\author{
1.1 Bologna process, competitiveness and university au- \\ tonomy
}

In the 1990s one of the predominant topics to emerge in the European higher education policy, was the notion that the European higher education was losing its competitiveness especially in relation to the American higher education system (Pépin 2007, Hackl 2001). Due to its strong brand, the US higher education institutions were able to attract many international students both from Europe, as well as from the large Asian markets, whereas the image portrayed by European higher education was considered weak and confusing. The wish of the European states to increase the competitiveness of their higher education and higher education institutions was one of the driving forces leading to the establishment of the Bologna Process and the European Higher Education Area (Amaral \& Magalhaes 2004). This was to be achieved through improving the comparability and quality of European of higher education degrees and increasing the mobility of graduates across Europe.

The strong emphasis on competitiveness in the Bologna Process, with close links to the European Union policy agenda (c.f. Corbett 2011, Hackl 2001), is framed in two ways. The first framing of competitiveness is related to the overall global influence that the European higher education is able to exert in the global field of higher education, as illustrated in the following quotes from the ministerial communications.

We must in particular look at the objective of increasing the international competitiveness of the European system of higher education. The vitality and efficiency of any civilisation can be measured by the appeal that its culture has for other countries. We need to ensure that the European higher education system acquires a worldwide degree of attraction equal to our extraordinary cultural and scientific traditions. (Bologna Declaration 1999)

The Bologna Process and the resulting European Higher Education Area, being unprecedented examples of regional, cross-border 
cooperation in higher education, have raised considerable interest in other parts of the world and made European higher education more visible on the global map. (Budapest-Vienna Communiqué 2010)

The wide global interest awakened by the Bologna Process is demonstrated e.g. in the joining of the countries in the outer edges of Europe in the Bologna Process; Kazakhstan being the latest country to join in 2010; and the wide interest on the process outside Europe (c.f.Adelman 2009). The Bologna policy forums; comprised of the representatives of the nonBologna countries world-wide and organised in Leuven/Louvain-a-neuve in 2009 and Vienna in 2010; recognised that countries outside the European higher education area "will now be able to more effectively foster collaboration with Bologna countries" (Bologna Process policy forum 2010, c.f. Zgaga 2007). Yet Bologna Process has also been argued to be used to insert European supremacy over other regions of the world (c.f. Robertson 2008).

This paper will focus on the second, more prominent framing of competitiveness. The global attractiveness of the European higher education is presented in most of the Bologna Process communications, and refers specifically to the ability of the European higher education institutions to attract international students and staff.

As the Bologna Declaration sets out, Ministers asserted that building the European Higher Education Area is a condition for enhancing the attractiveness and competitiveness of higher education institutions in Europe. (Prague Communiqué 2001)

Ministers agree that the attractiveness and openness of the European higher education should be reinforced. They confirm their readiness to further develop scholarship programmes for students from third countries. (Berlin Communiqué 2003)

Attractive working conditions and career paths as well as open international recruitment are necessary to attract highly qualified teachers and researchers to higher education institutions. (Leuven/Louvain-la-Neuve Communiqué 2009)

A set of principles, devised to guide the process, have been elaborated in the communications of the Bologna Process ministerial meetings. These include for example academic freedom, participation of stakeholders, the 
principle of education as a public good and public responsibility, as well as accountability combined with academic and institutional autonomy. Some of the principles, such as the participation of stakeholders is well engrained in the process, where as others, such as autonomy, along with diversity of languages, cultures and national education systems, have been argued to be mentioned as a lip service to already out-dated modes of thinking (c.f. Wächter 2004). In the documents constructing the Bologna Process discourse, autonomy has variably been presented either as a value in itself, or as instrumental to reaching specified goals, as below.

As we move closer to 2010, we undertake to ensure that higher education institutions enjoy the necessary autonomy to implement the agreed reforms, and we recognise the need for sustainable funding of institutions. (Bergen Declaration 2005)

Policy and research literature regularly argues for the autonomy of higher education institutions as the key to creating stronger, better, higher quality and more competitive universities, able to respond rapidly to the changing demands of their operational environment (Maassen and Olsen 2007, Aghion et al 2008, de Boer et al 2010, Jongbloed et al 2010). In the European higher education policy context, European University Association is one on the staunchest promoters of the University autonomy. EUA has worked extensively on university autonomy, including an Exploratory study charting the status of university autonomy in 34 European higher education systems (Estermann \& Nokkala 2009), a study on diversifying university funding streams which found that a university's ability to generate additional income relates to the degree of institutional autonomy (Estermann \& Bennetot Pruvot 2011), and the development of the autonomy scorecard, aimed to provide a tool for the universities to map the status of their autonomy vis-à-vis other countries (Estermann \& Nokkala 2011 forthcoming). In the Bologna Process, EUA has repeatedly framed autonomy as the precondition for the competitiveness of the European higher education.

Progress requires that European universities be empowered to act in line with the guiding principle of autonomy with accountability. As autonomous and responsible legal, educational and social entities, they confirm their adhesion to the principles of the Magna Charta Universitatum of 1988 and, in particular, to that of academic freedom. Thus, universities must be able to shape their strategies, choose their priorities in teaching and research, allocate their resources, profile their curricula and set their criteria for the ac- 
ceptance of professors and students. (EUA Salamanca declaration 2001)

Making European universities attractive for talented individuals and being able to offer them the appropriate career opportunities also requires strengthened autonomy. It is essential to ensure that university leaders are able to take the necessary decisions, especially in financial and staffing matters, to attract, remunerate, motivate and retain talented individuals at all levels. (EUA Aarhus Declaration 2011)

\subsection{Determining the question}

In the discourse of the Bologna Process, the notion of competitiveness as one of the process goals, and university autonomy as one of its founding principles, are consistently linked, thus justifying both. Autonomy is framed as a precondition of competitiveness, while competitiveness is framed in terms of attractiveness of European higher education and higher education institutions. Although the available data will not allow to decisively prove any causality, or lack thereof, between autonomy and attractiveness, in this exercise I will discuss their relationship and try to determine whether there is grounds for the repeated policy argument of their going hand in hand. Do the more attractive countries have higher autonomy, are the countries with higher autonomy more attractive? Or are these phenomena linked only in the simplified arguments of the policy discourse?

The first challenge is to decide which elements of university autonomy to focus on vis-à-vis the attractiveness of European higher education institutions. Previous research shows that the overall ability of the higher education institutions to decide on their strategic goals, programme offer and the allocation and composition of their funding maybe significant for the overall adaptiveness, and thus competitiveness, of the institutions (Sporn 2002); and that the performance of the higher education system is linked to the extent of autonomy of its universities (de Boer et al 2010; Jongbloed et al 2010). The Bologna Process, however, focuses less on the governance and funding of higher education institutions, and more on the organisation of degree programmes, and on the introduction of tools to support the mobility of staff and students in Europe. The Bologna Process may be perceived to be driven by the perspective of socio-cultural exchange as well as the perspective of liberalising the markets for higher education and academic labour (c.f. Cradden 2007, 9). Following the EUA discourse, it 
seems logical to focus on the ability of higher education institutions to decide upon the activities pertaining directly to their potential students and staff.

Therefore, in the following "autonomy related to attracting students" is operationalised as the ability to the institutions to decide to open up new degree programmes, intake of new students, and to set the tuition fees. "Autonomy related to attracting staff" is operationalised as the ability of the institutions to decide on the recruitment and salaries of (academic) staff. The autonomy elements used in the following are based on the study Estermann \& Nokkala $2009^{1}$. The discussion will be limited to public universities, and private universities and other higher education institutions will not be covered.

The second challenge is to decide how attractiveness is to be measured. If attractiveness is seen to encompass the ability to be attractive for both international students and staff on the other, it can operationalised as the flows of foreign students and staff into each country. A series of proxies are used for indicating the student and staff flows, as little comperehensive data is available. The data on student flows relies to a large extent on the OECD Education at a Glance -series, while the data on staff flows, less readily available, is partially based on OECD, partially various European Union data.

The analysis below covers 26 countries $^{2}$ which are all members of the Bologna Process, although not all are members of the European Union. The countries were selected based on a convenience sample, namely of having data available on most of the discussed autonomy elements and attractiveness proxies. However, there are some instances in which the complete data on student and staff flows is not available. The data on autonomy elements and attractiveness proxies pertains mostly to 2008, again with individual exceptions. The tables combining statistics and autonomy data,

${ }^{1}$ A more updated version of the autonomy data is available in Estermann and Nokkala (2011 forthcoming). However, at the time of writing this chapter, that is still under embargo.

${ }^{2}$ Austria, Cyprus, Czech Republic, Denmark, Estonia, Finland, France, Germany, Greece, Hungary, Iceland, Ireland, Italy, Latvia, Lithuania, Luxembourg, the Netherlands, Norway, Poland, Portugal, Slovak Republic, Spain, Sweden, Switzerland, Turkey and United Kingdom. 
which form the basis of the analysis, are included in the annexes 1 (students) and 2 (staff).

\subsection{Attractiveness for students}

\subsubsection{Success dimensions in student attractiveness}

The international markets in higher education have expanded substantially in the past 35 years. Where in 1975 approximately 0,8 million tertiary education students studied outside their own countries globally, in 2000 the figure was already 1,8 million. The growth has accelerated in the past decade; the overall number students studying outside their country had grown globally to over 3.3 million in 2008, and has been predicted to rise to 7.2 million by 2025. (OECD 2010, Böhm et al. 2002.) The large OECD countries: United States, United Kingdom, Germany, France and Australia, were the most significant destination countries for foreign students, while the largest sending countries were China, India, Korea, France and Germany (OECD 2010). International students represent an important source of revenue for countries and higher education institutions; additionally they are considered potential future knowledge workers in the national economy, and provide important cultural and social contribution to the learning environment at higher education institutions (Knight 2004, Verbik and Lasanowski 2007, Lee et al 2008).

In the following exercise, four measures are taken as proxies for the attractiveness of European higher education to internationally mobile students:

- the share of foreign students in a given country out of all internationally mobile students,

- the ratio of foreign students our of all tertiary education type A students in a given country,

- the ratio of students coming from EU193 countries out of the foreign students, and

- the change in the number of foreign students in a given country from 2000 to 2008 .

Based on these, three success dimensions of student attractiveness can be constructed:

${ }^{3}$ EU19: AT, BE, CZ, DK,FI, FR, DE, GR, HU, IE, IT, LU, NL, PL, PT, SK, ES, SE, UK. 
- important study destinations: the countries included in the OECD 2010 list of largest receiving countries

- high foreign student ratio: countries with the share of foreign students at least $10 \%$ of all tertiary type A students

- significant risers: index of change in the number of foreign students 2000-2008 250 or over.

The success dimensions are then analysed in relation to the different autonomy elements related to the ability of the universities to attract students: the ability to open new programmes, to decide on the overall student numbers and to set the tuition fees. The tuition fee element is elaborated with the information about the amount of tuition fees and the share of tuition fees for the entire university revenue ${ }^{4}$. The compilation tables of the different elements are included in annex 1.

The leading European host countries for foreign students are UK, which hosts $10 \%$ of the world's internationally mobile students, followed by Germany and France, both with 7.3\%. Far behind these come Italy (2\%), Spain (1.9\%), Austria (1.6\%), Switzerland (1.4\%), the Netherlands (1.3\%) and Sweden (1\%). Two European countries included in the list of biggest receiving countries, but excluded from our current discussion are Russia with $4.3 \%$ and Belgium with $1.3 \%$ share on internationally mobile students. (OECD 2010).

Considering that the overall number of foreign ${ }^{5}$ students has grown globally, it is unsurprising that the number of foreign students in the Bologna Process participating countries has also increased between 2000 and 2008. The OECD Education at a Glance 2010 gives data on foreign students studying in tertiary type A programmes 6 , as well as the index of

\footnotetext{
${ }^{4}$ I consciously refrain from using the statistical terminology such as dependent and independent variables and correlation.

${ }^{5}$ OECD uses the concept of foreign students to denote those students who do not have the citizenship of the country in which they study, and international students to denote the students who have entered the country specifically with the intention to study there. The measure of foreign students is selected in the following, as many countries do not differentiate between international and foreign students, and thus the figures for international students are less often available.

${ }^{6}$ Tertiary type A - programmes are ISCED5A level, and are typically theorybased and last at least three years. As this paper focuses on universities rather than
} 
change in the number of foreign students 7 in total tertiary level. The index shows growth in the numbers of foreign students of all tertiary education students in all countries included, in ten countries the numbers of international students has doubled or more.

The largest percentage of foreign students out of all students in tertiary type A education can be found in UK (20.8\%), Austria (18.8\%), Switzerland (17.9\%), France (12.4\%) and Germany (12.2\%). These are the only countries in the list, where the share of foreign students exceeds $10 \%$ of all tertiary type A students. All of these countries also hold key positions in OECD list of the largest host countries for foreign students. Other important host countries, Italy and Spain, which have large higher education systems, do not have a large ratio of foreign to domestic students; while important host countries with relatively smaller higher education systems such as the Netherlands and Sweden fair better in terms of their foreign student ratio.

Interestingly, the biggest risers in terms of having increased their foreign student population are Czech Republic and Slovak Republic, of which the former had five times as many foreign students in 2008 as in 2000. In Slovak Republic the number had increased to almost 3,5 times in the same period. The two countries also had the highest percentage of foreign students coming from the other $\mathrm{EU}^{8}$ countries: in Czech Republic the figure was $73.4 \%$ and in Slovak Republic $67.8 \%$. Other countries to have significantly (over 2.5 times) increased their number of foreign students were Greece, the Netherlands, Estonia, Italy and Spain; of these also Estonia and the Netherlands had high share (over 50\%) of their foreign students coming from other EU countries.

Of the significant risers, Czech Republic, Slovak Republic, Estonia and the Netherlands had high share of their foreign students from the other EU countries. On the other hand, the other significant risers, Greece, Italy and Spain, did not have a high percentage of students from other EU members.

other tertiary education, the tertiary type A figure is chosen instead of the total tertiary education.

${ }^{7}$ Index pertains to total tertiary enrollments as no tertiary type A figure is available.

${ }^{8}$ EU19. 
At the same time, Europe's biggest competitors; United States - as the largest economy in the world, and the most popular study abroad destination, and Australia - as the education super power in the South-East Asia, and the second most popular non-European study destination; have seen more modest growth in the number of foreign students. In Australia, the number of foreign students has more than doubled between 2000 and 2008 (index 218), while in US the growth index shows more moderate growth at 131, well under the OECD average of 263 and the EU average of 220. The US share of the world's mobile students in 1998 was $34 \%$, and in 2008 18.7\%. This means that the United States has lost its competitiveness to the other countries. The reasons for that are manifold both in US and in the gaining regions, including Europe. The sometimes prohibitive cost of education in US has made studying there less attractive, and the tightening of the visa regulations, most specifically after $9 / 11$, have made it more cumbersome (Verbik and Lasanowski 2007). At the same time, the expansion of English language educational offer in traditionally non-English language countries has made studying there more attractive. Also the Bologna reforms may have made Europe a more attractive study destination, although it is impossible to show direct causality.

1.3.2 Success dimensions, student intake and opening new programmes

The first autonomy element is the ability of the universities to decide on their student intake. According to Estermann \& Nokkala (2009) the overall student numbers are exclusively decided by universities in Denmark, Estonia, Ireland, Luxembourg, and Poland. There are also two collaborative systems: a split system where the universities decide on fee-paying, state on state-funded study places (Czech Republic, Latvia, Portugal) and a negotiated system, where the universities negotiate with an external authority (Cyprus, Finland, Germany, Hungary, Iceland, Slovak Republic, Sweden, and UK). The universities in these countries may be said to have large autonomy to decide on student intake.

In those countries, where there is a free admission (Austria, France, Italy, the Netherlands, Spain and Switzerland) or where the decision about the overall student numbers resides solely on the external authority (Greece, Lithuania, Norway and Turkey) the autonomy may be characterised as small.

Of the important study destinations, UK, Germany and Sweden have large autonomy, while in France, Switzerland, Italy, Spain, and the Netherlands the autonomy is small. Of the countries with high foreign student ra- 
tio, large autonomy applies similarly to UK and Germany, but not to France, Switzerland and Austria, all of which incidentally have free admission to universities for all eligible applicants. Amongst the biggest risers the picture is similarly blurred: the autonomy is large in Czech Republic, Estonia and Slovak Republic, but small in Greece, Spain, Italy and the Netherlands.

The second autonomy element is the ability of the universities to open new programmes to attract students. The universities in Switzerland, Norway and Sweden are very autonomous in this regard. Of these, Switzerland and Sweden are also amongst the most important study destinations, and Switzerland has high foreign student ratio. Other countries, regardless of their performance on the success dimensions have less university autonomy in opening programmes. Universities either have to acquire accreditation prior to opening the programme, or engage in negotiations regarding the resources required for their opening. Also other, more precise restrictions may exist, such as only being able to open programmes that pertain to the education remit of the institution (Finland and Luxembourg), or a different process existing for opening programmes that are on the nationally accepted list of accredited programmes, and new programmes not yet on the list (Slovak Republic and Hungary) (Estermann \& Nokkala 2009). Different procedures may be in place for Bachelor, Master and Doctoral degrees, or programmes not leading to any of the aforementioned qualifications.

\subsubsection{Success dimensions, market-drivenness and tuition fees}

The third autonomy element is related to the market-drivenness of the system, and the ability of the universities to set tuition fees for their degree programmes. In policy discourse, a relationship is often perceived to exist between the market-drivenness of a higher education system, and its ability to attract internationally mobile students. For example the leading host countries for higher education, US, UK and Australia, have created diversified markets by strategically targeting students in potentially high-yield countries, as well as taken steps to ensure the successful arrival and integration of foreign students (Verbik and Lasanowski 2008). Cradden (2007) on the other hand, argues that the premises of the Bologna Process imply a commitment to the principle of human capital development on a competitive basis and that the needs for higher education should be determined from the perspective of labour markets rather than political, cultural or administrative aims arising outside it. Therefore, the Bologna Process can also be interpreted as a process of labour market reform intended to con- 
tribute to the realisation of a market-driven European higher education system. (Cradden 2007.)

While no direct connection to Bologna Process can be shown, some European countries such as Denmark, Sweden and Finland, have in recent years introduced tuition fees for non-EU students with the argument that tuition fees contribute much-needed funds for the higher education institutions and contribute to the perception of quality in the higher education(c.f. Regeringskansliet 2010). Therefore the reliance of universities on tuition fees, and the extent of "market-drivenness" they represent, merit a discussion here.

According to a recent CHEPS-led study (Jongbloed et al 2010, 47-48), in 2008 the share of tuition fees in the public universities varied between zero percent in Finland and Sweden, to 35\% in Ireland. The importance of tuition fees in relation to the total university income was $20 \%$ or more in Ireland, Lithuania, UK, Poland and Spain. Of these, the UK and Spain are significant host countries for foreign students. UK also has the largest foreign student ratio in tertiary education $(20.8 \%)$, and the number of foreign students has increased by 50\% from 2000 to 2008; a relatively modest growth compared with some countries, but significant considering the huge number of its foreign students to start with. Ireland is not a significant destination, its foreign student ratio is also modest, but at 35\% of the university revenue, its reliance of tuition fees is great. Also in Poland ${ }^{9}$ (22\%) and Spain (21\%) tuition fees make up a significant portion of the budget, and similarly the number of foreign students has increased quite significantly. Of these, Spain is also a significant destination in the global scale. On the other hand, for example France is also significant destination, with large foreign student ratio (although with a relatively modest rise in the number of foreign students), but the reliance of universities in tuition fees is small (5\%).

Similarly, a question may be raised about the relationship between the amount of tuition fees and the extent of university autonomy.

According to a study by Jongbloed et al. (2010, 62-63) the amounts of tuition fees in public universities in 2008 at the Bachelor level were either non-existent or relatively low, typically less than $€ 1000$ per annum. At Master level there may be fees even on cases where there are non at BA-

\footnotetext{
${ }^{9}$ It must be noted though, that in Poland tuition fees are paid only by part time students, who make a very significant part of the overall student population.
} 
level, or the fees may be higher. The fees for non-EU students are often higher than for EU-students, or there maybe fees for them, even if the education for national/EU students is free of tuition.

The fees were relatively high, typically more than $€ 1000$ per annum at Bachelor and Master level for example in UK, Spain, and the Netherlands, and at Master level only in Ireland, Luxembourg, Greece and Cyprus. Of these countries, only UK, Spain and the Netherlands are significant destinations, and only Greece, the Netherlands and Spain have experienced a significant rise in the number of foreign students. On the other hand, there were no fees in countries like Czech Republic, Slovak Republic or Estonia, which have significantly increased their number of foreign students, although they are not significant study destinations on the whole.

The overall picture emerging in terms of the ability of the public universities in some of the EU-member states to set the fees for the national/EU, and non-EU students, is that the universities in a minority of countries have large freedom to set the tuition fees. This means that they are able to set the fees freely or in cooperation with national authorities; this was the situation in Cyprus, Estonia, Greece, Hungary, Latvia, Lithuania, Luxembourg, Poland and, with some limitations, UK. In majority of the systems, the universities had relatively small freedom in setting fees. There were either no fees at all (Austria, Czech Republic, Denmark, Finland, Iceland, Norway, Slovak Republic and Sweden, and for Bachelor degrees in $\mathrm{Cy}-$ prus, Greece and Scotland); the fees were set by external authority or law (France, Ireland, Netherlands, Spain, Switzerland and Turkey); or the universities were only able to set fees under a ceiling determined by public authorities (Italy, Portugal, and Bachelor degrees in England). It is important to note that the data described above refer only to the main body of students at Bachelor and Master levels, on-campus, full-time national and EU-students. There may be different processes in place for part-time or non-EU students, or students at doctoral programmes 10 .

Therefore, of the important destination countries, only UK has large freedom to set tuition fees, and even that is limited at the Bachelor level. The universities in the other important destination countries: Germany, France, Italy, Spain, Switzerland, Austria, Netherland or Sweden don't have a large freedom to set fees. Of the significant risers, Estonia, and Greece give universities large freedom to set fees.

${ }_{10}$ More comprehensive picture will be available in Estermann and Nokkala 2011 forthcoming. 
We may therefore conclude that the picture given by the different success dimensions in attracting foreign students is mixed. The important study destinations seem to have variable foreign student ratios, when the perspective is moved from the examination of the global picture to the situation inside the country. Similarly the biggest rises in the numbers of foreign students included both countries that were significant destinations countries, but also a score of countries that were neither significant destinations, nor reached large foreign student ratios as a result of the change.

The link between high tuition fees, significance of tuition fees for the total university budget, or the autonomy to set fees and the success in attracting international students seems to be tenuous. The other important student related factors, namely the ability to decide on student intake and to open new programmes seem to bear similarly weak connection to the three success dimensions in student attractiveness.

\subsection{Attractiveness for staff}

\subsubsection{Success dimensions in staff attractiveness}

Much work has been done about the mobility of highly skilled scientific labour force, pertaining for example to the specific situations in different countries (Ackers and Gill 2005, Stretenova 2003); relationship between mobility and knowledge and technology transfer (Ackers and Gill 2008, Miguélez et al 2009); mobility in different disciplines (Ackers and Gill 2005 ) and the motivations of scientific mobility (Ackers 2005, Iredale 1999, Marton-Rover 2003). Data is also available on the European mobility at large (e.g. European Commission 2008) and on mobility in specific fields such as science and technology (e.g. Eurostat 2007). Yet the scarcity of comprehensive European data about academic staff mobility is recognised, and statistics that would allow for the compassion of then different European countries are scarce (Pontén et al. 2007, OECD 2007). If statistics are collected at all, they are typically collected by different countries individually, using variable definitions of mobility, educational level and occupational categories. This makes cross-country comparisons well nigh impossible and hinders the implementation of the European mobility strategy (European Commission 2008).

Much of the EU researcher mobility takes place between the EU countries, and most mobile researchers are mobile between the five largest EU 
economies: UK; France, Germany, Italy and Spain. The mobility of the non-EU researchers is hypothesised to be hindered mostly by visa and residence-permit issues. (European Commission 2008.) All in all, the researcher mobility is at a low level: in the ten countries participating in the recent RESCAR study ${ }^{11}$ of $\mathrm{PhD}$ candidates $7.3 \%$ were born in another EU member state, and 2.5\% in other European, but non-EU country. The numbers for $\mathrm{PhD}$ candidates born outside Europe were somewhat higher. At postdoctoral level, $13 \%$ were from other EU countries, and 4\% from other European, non-EU countries. The figures for non-European post-docs were at a similar level. According to the RESCAR study, United Kingdom, France and Spain were gaining $\mathrm{PhD}$ candidates and post-docs, whereas Czech Republic, Hungary and Portugal were losing. There was virtually no $\mathrm{PhD}$ candidate mobility from US to Europe, although at post-doctoral level there was some re-migration from US to Europe: 3\% of European postdocs obtained their doctorates in US, while $1.5 \%$ were born in US. (European Commission 2008, 15-16.) While the figures regarding the mobility of highly-cited researchers are largely anecdotal, the relatively low number of highly-cited researchers in Europe compared with US, and the largely European background of the highly-cited researchers affiliated with US institutions have been a sources of concern (c.f. Winkler 2007).

Cradden (2007) uses four categories to define the different modes of staff mobility based on the extent of the 'attachment' to the host institution in a foreign country: visits, exchanges and sabbaticals; grants and fellowships; untenured/insecure employment, and tenured/secure employment. $\mathrm{He}$ also determines two institutional and/or system-level rationales for the mobility: a socio-cultural and scientific project facilitating inter-cultural exchange and sharing knowledge across borders, or a contribution to a single European academic labour market organised along the principles of a market-driven higher education system (Cradden 2007). These two rationales take prominence in the different stages of the academic career.

Based on the classification of these two rationales, and the four modes of mobility, Cradden distinguishes four different mobility categories:

- traditional academic exchanges (short term visits and sabbaticals),

- early career training and experience (grants and fellowships, untenured),

${ }^{11}$ Countries included in the study were Czech Republic, Germany, Spain, France, Hungary, Italy, Norway, Portugal, Sweden and UK. Robinson et al 2007, cited in European Commission 2008, 15-16. 
- importing cheap academic labour (grants and fellowships, untenured), and

- targeting the International labour market (tenured).

In the first two categories, socio-cultural motivations prevail, while the latter categories fall under the market emphasis. As so little consistent data is available, a number of proxies must be used to illustrate the different categories of staff mobility. There is, however, no convenient proxy for the category of importing cheap academic labour. An obvious one to suggest itself, would be the related to the mobility of staff from low GDP to high GDP countries, but as this would necessitate a comparison between the salaries paid in the host countries to staff coming from low vs. high countries, I will leave out that category.

In the following examination, three measures are taken as proxies for the attractiveness to staff:

- The number of incoming and outgoing Erasmus teachers in a given country in academic years 2004-2005 and 2009-2010. This is used as a proxy for the traditional academic exchange.

- The ratio of foreign $\mathrm{PhD}$ students out of all $\mathrm{PhD}$ students in a given country and the change in the share of foreign PhD students out all $\mathrm{PhD}$ students in a given country from 2004 to 2008. This is used as a proxy for the early career training and experience.

- Percentage of foreign highly-cited researchers born elsewhere but working in the country, and of those born in the country and working elsewhere. This is used as a proxy for the category 'targeting the international labour market'.

Based on these, four success dimensions for staff attractiveness can be constructed:

- Significant Erasmus risers: growth in the incoming and outgoing Erasmus teachers at least 50\%

- High foreign $\mathrm{PhD}$ student ratio: countries with the share of foreign $\mathrm{PhD}$ students at least $20 \%$ of all $\mathrm{PhD}$ students

- Significant PhD risers: growth in the PhD student ratio from 2004 to 2008 at least five percentage points

- Mobility of highly-cited researchers

The aforementioned success dimensions are analysed in relation to the different autonomy elements related to the ability of the universities to attract staff: the ability to decide on staff recruitments and salaries for indi- 
vidual staff members. The salary element is elaborated with the information about the average salaries junior and senior level. The compilation tables of the different elements are included in annex 2.

The first measure; Erasmus teacher mobility; only address the intraEuropean mobility, and disregards the mobility to and from the countries outside Europe. It also excludes research-related short term mobility which is integral to the category of traditional academic exchange, thus making it a rather poor proxy for this category. The average duration of the Erasmus teacher exchange is between five and seven days.

The European Commission Erasmus statistics show that overall, the teacher mobility within the Erasmus framework has increased over the years. The Erasmus statistics for all the eligible countries have shown a fourfold increase from the 7,797 mobile teachers in the academic year 1997-1998 to 29,031 in 2009-2010. France, Germany, Italy and Spain were the most popular destinations in Erasmus teacher mobility, all with more than 2500 visiting Erasmus teachers per year. The same countries are sending out some of the largest cohorts of Erasmus teachers, although Poland with 2967 was at the top of the list. In terms of the increase in the incoming Erasmus teachers, biggest increases are in Turkey, Slovak Republic, Latvia and Estonia, and in the outgoing mobility in Turkey, Slovak Republic and Poland, all which at least doubled their Erasmus mobility between 2004 and 2009. Lithuania, Cyprus, Hungary, Iceland, Poland and Czech Republic followed closely behind. The only countries where the numbers decreased were Luxembourg (incoming) and Denmark (outgoing). The biggest increase in outgoing teachers has similarly been in Turkey, Slovak Republic, Poland, Hungary and Latvia, reflecting the reciprocal nature of the programme. (European Commission 2011.)

The proxy for early career training and experience is the percentage of foreign students in advanced research programmes, i.e. at $\mathrm{PhD}$ level. This proxy also has some limitations, because the status of PHD candidates varies significantly between countries: $\mathrm{PhD}$ candidates are in some countries employed as staff members, in others they are fee-paying students. The OECD has statistics available from 2004 (OECD 2006) and 2008 (OECD 2010), showing steady growth in the percentage of foreign students out of all students at $\mathrm{PhD}$ level, despite the short lapse of time. At the same time, the OECD average in 2004 was $19.5 \%$ and in $200821.1 \%$. The corresponding figures for EU19 were $16.7 \%$ (2004) and 18.6\% (2008). The largest foreign $\mathrm{PhD}$ student ratios in 2008 were in UK (47.7\%), Switzerland (45.9\%) and France (39.8\%), with Austria (26.0\%), Norway (25.5\%), 
Spain (24.0\%) and Sweden (23.7\%) following closely behind. Except for Norway, these countries are also important destinations for foreign tertiary level A students, and most of them were also significant risers in terms of the ratio of $\mathrm{PhD}$ students are UK (7.4 percentage points), Norway (6.8pp), Spain (6.5pp), France (5.9pp) and Switzerland (5.5pp). It is interesting to note, however, that the ratio of foreign $\mathrm{PhD}$ students has fallen in Denmark, although it has risen in all the other countries where data is available for both 2004 and 2008. This paper is not, however, able to speculate the causes for this development.

The data on the mobility of the successful, typically tenured academics is the most challenging to come by. Cradden $(2007,35)$ provides the data on incoming and outgoing mobility of highly-cited researchers in the mostprominent higher education systems in Europe, presumably with the largest shares of mobile highly-cited researcher. This data on in is used as a proxy for the mobility category 'targeting international labour market'.

The most active country to send hi-ci researchers elsewhere is Germany, with $43 \%$ of hi-ci researchers born in this country working elsewhere. This was followed by Italy (19\%), the Netherlands (10\%), UK (9\%) and France $7 \%$. The country to attract most hi-ci researchers from other countries was Switzerland with $64 \%$, followed by Germany (27\%), UK (19\%), France (18\%) and the Netherlands (10\%). Of these countries, the Swiss universities are most international: as many as $88 \%$ of the hi-ci researchers working in Swiss universities have some foreign experience. Also in Italy $(61 \%)$, Germany $(53 \%)$ and the Netherlands $(50 \%)$ at least half of the hi-ci researchers have some international experience. (Cradden 2007, 35.)

The data on the interrelations of the different dimensions seems to indicate the existence of two clusters of international activity. On the one hand, a cluster of western European countries with strong higher education systems, which appear on the list of the highly-cited researchers' mobility, have the largest foreign $\mathrm{PhD}$ student ratios, and have experiences the largest increase in those. These countries were also amongst the biggest senders and receivers in Erasmus teacher mobility. On the other hand, the increase in the incoming and outgoing Erasmus teacher activity has been largest in the emerging countries of the central/eastern/southern Europe, which seems to indicate the those countries are picking up on the internationalisation bandwagon, perhaps as a result of the European internationalisation efforts.

1.4.2 Success dimensions and the autonomy to attract staff 
What then is the extent of the autonomy of the universities to decide on the staff-related aspects?

The first autonomy element is the ability of the universities to decide on staff recruitment. Universities were able to freely recruit senior academic staff in $2008^{12}$ in Estonia, Germany, Ireland, Latvia, Luxembourg, the Netherlands, Norway, Switzerland and UK. Of these, Germany, the Netherlands, Norway, Switzerland and UK perform well in most of the success dimensions for staff attractiveness. In the remaining countries, either the number of posts were regulated by external authorities (Cyprus, France, Greece, Portugal and Turkey), or there were other specifications for recruitment in the law (Austria, Czech Republic, Denmark, Finland, Hungary, Iceland, Italy, Lithuania, Poland, Slovak Republic, Spain and Sweden). The ability to recruit international staff may be hindered by complicated in recruitment procedures in some countries, though. In Slovak Republic and Spain, a specific personal "accreditation" was required of all those wishing to apply for professorial posts (Estermann and Nokkala 2009). It may be noted, that several well-performing countries, for example France, Spain and Italy, have little freedom to recruit staff.

The second autonomy element is the ability of the universities to decide on staff salaries. Drawing from the data provided by the national members of the Education International, Cradden $(2007,43)$ concludes that the salaries of the academic staff at junior and senior level display great variation, both between countries. For those countries where this data is available, the average salaries at the most senior level range from $€ 87,500$ in UK and $€ 86,400$ in Denmark to $€ 56000$ in Spain. The average salaries for the most junior level range from $€ 43,800$ in Norway and $€ 42,500$ in Sweden to $€ 18,368$ in Spain and $€ 11,857$ in Italy. Outside the more internationally successful higher education systems, the minimum salaries in Latvia may be as low as $€ 2,688$ per annum at the must junior, and $€ 13,406$ per annum at the most senior level. (Cradden 2007, 43)

There is little possibility to look at the co-occurrence of high senior salaries and hi-ci mobility. However, UK features in both lists, with high abil-

\footnotetext{
12 After that, there have been some changes e.g. in Finland, where the universities in 2010 gained full employer position (see www.minedu.fi) and Ireland, where the universities have faced restrictions in recruitment and conditions of employment since the outset of the severe economic depression in 2008 (see www.hea.ie).
} 
ity to pull international highly-cited researchers, and having high average senior salaries. Norway, Sweden and UK all have a high foreign $\mathrm{PhD}$ student ratios (UK and Norway have also increased that ratio significantly), and they have high average junior salaries.

In terms of the autonomy to decide on staff salaries, universities had large freedom to set staff salaries in nine countries: in Czech Republic, Estonia, and Norway they were able to set the salaries for all staff and in Austria, France, Germany, Italy, Portugal and Spain for some. In other countries universities had small freedom to set salaries, namely, salaries were either prescribed by other bodies (Cyprus, Greece, Ireland, Turkey) or universities were able to set the salaries only within limits (Denmark, Finland, Hungary, Iceland, Latvia, Lithuania, Luxembourg, the Netherlands, Poland, Slovak Republic, Sweden, UK). (Estermann and Nokkala 2009.)

The countries where the universities are free decide on the staff salaries and do well in terms of the success dimensions include Austria, France, Norway, Spain and Germany. But not all countries where the ability to decide on staff do well in terms of internationalisation (Czech Republic, Estonia and Portugal); and in some countries who do well on internationalisation, such as Switzerland and UK, the universities are not entirely free to decide on salaries 13 .

It seems, therefore, that the autonomy elements related to the university ability to decide on staff-related issues, do not give a conclusive picture in terms of the success of the national higher education systems to attract foreign staff. There may be other elements of autonomy which bear a closer relationship with attractiveness, such as the financial autonomy of universities. The factors inhibiting researcher mobility included the lack of recognition of and lesser opportunities for career progression linked to mobility, lack of funding opportunities supporting mobility, and lack of job security and stability in research careers. Also immigration rules may hinder mobility especially for researchers outside European countries. (European Commission 2008, Cradden 2007.)

\subsection{Discussion}

13 However, looking at the 2010 autonomy data, the situation would look somewhat different. Estermann and Nokkala 2011 forthcoming. 
In the European policy discourse, the university autonomy is often mentioned as one of the integral elements in increasing the attractiveness of the European higher education system. This paper set out discuss the link between the university autonomy, focussing specifically on the ability of the universities to decide on issues related to student and staff, and the attractiveness of the higher education system, operationalised through various figures on international students and staff flows in the different Bologna Process member countries.

The results were not conclusive. Although it is fairly easy to determine the "winners" of the European internationalisation effort, the autonomy of the universities to decide on student and staff issues did not present any clear picture. The countries doing well on the different success dimensions had varying levels of autonomy. Similarly, the elements of autonomy did not necessarily correlate between themselves.

It seems all in all, that the claim about the relationship between university autonomy and the attractiveness of the higher education systems are founded on political rhetoric rather than actual figures on the staff and student flows. Perhaps this lack of evidence about their link lends support to the idea of the tokenistic use of autonomy in the Bologna Process discourse (c.f. Wächter 2004), and the reasons for the success of some of the European higher education systems in attracting international students are found elsewhere. As previous studies show, other factors, such as language, immigration policies, images and available funding play an important role in internationalisation. Also the economic and political developments in sending and receiving countries, not covered by the discussion here, undoubtedly play a role.

There are, however, a few other important aspects to consider. The first of these is the pulling power of few elite institutions in the countries like UK, France, Germany or Switzerland. These may attract large numbers of international students and staff and their relative significance in the national higher education system may be bigger than their size would otherwise suggest. This would explain the discrepancy in some countries between high overall share of internationally mobile students and relatively low portion of international students out of all students in the national higher education system. The pulling power of elite institutions is also an important notion behind the ubiquitous world class university discourse.

The second is the role of autonomy itself. Instead of a simple case of cause and effect, autonomy maybe considered one of the perhaps many mediating or catalytic elements in the attractiveness: autonomy may be 
needed for the other pulling factors to be achieved; or it may help them go further.

Nevertheless, these considerations does not remove the problem of lacking comprehensive comparative data on student and staff mobility, which turned out to be one of the greatest challenges of this exercise. In order for the European policy makers to make conclusions about the relationship between university autonomy and attractiveness to students and staff, or indeed about any European policy measures related to attractiveness; up-todate, comparable statistics about student and staff mobility are needed. A further analysis is also needed on the different markets of staff and student mobility.

\subsection{References}

Ackers, L. (2005). Moving people and knowledge: Scientific mobility in the European Union. International Migration, 3(5): 99-131.

Ackers, L. and Gill, B. (2005). Attracting and retaining 'early career' researchers in English higher education institutions. Innovation, European Journal of Social Science Research, 18(3):277-299.

Ackers, L. and Gill, B. (2008). Moving people and knowledge: scientific mobility in an enlarging European Union. Cheltenham: Edward Elgar.

Adelman, C. (2009). The Bologna Process for U.S. Eyes: Re-learning Higher Education in the Age of Convergence. Washington: Institute for Higher Education Policy.

Aghion, P., Dewatripont, M., Hoxby, C., Mas-Colell, A., Sapir, A. (2008). Higher Aspirations: An agenda for reforming European universities. Bruegel Blueprint Series V. Brussels: Bruegel.

Amaral, A. and Magalhães, A. (2004). Epidemiology and the Bologna Saga. Higher Education, 48(1):79-100.

Bergen Communiqué 2005.

Bologna Declaration 1999.

Bologna Process policy forum (2010). Bologna policy forum statement. March 12, 2010. Vienna, Austria. 
http://www.ond.vlaanderen.be/hogeronderwijs/bologna/forum2010/Vie nna_BPF_Statement.pdf Retrieved 1.9.2011.

Budapest-Vienna Communiqué 2010.

Böhm, A., Davis, D., Meares, D., \& Pearce, D. (2002). Global student mobility 2025: Forecasts of the global demand for international higher education. Sydney: IDP Education Australia.

Corbett, A. (2011). Ping Pong: Competing leadership for reform in EU higher education 1998-2006. European Journal of Education, 46(1): 3653.

Cradden, C. (2007). Constructing Paths to Staff Mobility in the European higher education Area: From Individual to Institutional responsibility. Brussels: Education International.

London Communiqué 2007.

De Boer, H.; Jongbloed, B.; Enders, J. \& File, J. (2010). Progress in Higher education reform across Europe: Governance reform. Report commissioned by the Directorate General for Education and Culture of the European Commission. Brussels: EC.

Estermann, T. and Bennetot Pruvot, E. (2011). Financially Sustainable Universities II: European universities diversifying income streams. Brussels: EUA.

Estermann, T. and Nokkala, T. (2009). University Autonomy in Europe I. Exploratory study. Brussels: EUA.

Estermann, T. and Nokkala, T. (2011 forthcoming). University Autonomy in Europe II. The Scorecard. Brussels: EUA

European Commission (2006). European and Mobility. First results on an EU-wide survey. Brussels: EC. 
European Commission (2008). Evidence on the main factors inhibiting mobility and career development of researchers. Report by Idea-Consult, Frauenhofer-ISI, NIFU-STEP, PREST, SPRU and Technopolis. Brussels: EC.

European Commission (2011). Erasmus statistics. http://ec.europa.eu/education/erasmus/doc920 en.htm Retrieved 1.9.2011

Eurostat (2007). How mobile are highly qualified human resources in science and technology. Statistics in Focus, 75/2007. Luxembourg: Eurostat.

EUA (2001). Salamanca Declaration. The Bologna Process and the European Higher Education Area. Brussels: EUA.

EUA (2011). Aarhus Declaration. Investing Today in Talent for Tomorrow. Brussels: EUA.

Hackl, E. (2001). The intrusion and expansion of Community policies in higher education. Higher Education Managemen, t 13(3): 99-117.

Iredale, R. (1999). The need to import skilled personnel: the factors promoting and hindering its international mobility. International Migration, 37(1): 89-111.

Jongbloed, B.; De Boer, H.; Enders, J. \& File, J. (2010). Progress in Higher education reform across Europe: Funding reform. Report commissioned by the Directorate General for Education and Culture of the European Commission. Brussels: EC.

Knight, J. (2004). Internationalization remodeled: Definition, approaches and rationales. Journal of Studies in International Education, 8(1): 5-31.

Lee, J.; Maldonado, A. \& Rhoades, G. (2008). The Political Economy of International Student Flows: Patterns, Ideas, and Propositions. In: Smart, John C. (Ed). (2008). Higher Education: Handbook of Theory and Research, 21: 545-590. Dordrecht: Springer.

Leuven/Louvain-la-Neuve Communiqué 2009. 
Maassen, Peter and Olsen, Johan P. (Eds) (2007). University Dynamics and European integration. Dordrecht: Springer.

Martin-Rovet, T. (2003). Opportunities for Outstanding Young Scientists in Europe to Create an Independent Research Team. Strasbourg: European Science Foundation.

Miguélez, E.; Moreno, R. \& Suriñach, J. (2009). Inventors on the move: tracing inventors' mobility and its spatial distribution. Research Institute of Applied Economics, Working papers 2009/16. Barcelona: University of Barcelona.

OECD (2007). Workshop on the International mobility of Researchers. $28^{\text {th }}$ March 2007, Paris, France.

http://www.oecd.org/document/5/0,3343,en_2649_34269_38004805_1_1_ 1 1,00.html Retrieved 1.9.2011

OECD (2000). Education at a Glance 2000. Paris: OECD.

OECD (2006). Education at a Glance 2006. Paris: OECD.

OECD (2010). Education at a Glance 2010. Paris: OECD.

Pepin, Luce (2007). The History of EU Cooperation in the Field of Education and Training: How Lifelong Learning Became a Strategic Object. European Journal of Education, 42(1): 121-132.

Pontén A. and the Bologna Process Working Group on Social Dimension and the Data on the Mobility of Staff and Students in Participating Countries (2007). Key issues for the European Higher Education AreaSocial Dimension and Mobility. Stockholm: The Ministry of Education and Research.

Prague Communiqué 2001.

Regeringskansliet (2010). Competing on the basis of quality - tuition fees for foreign students. The Ministry of Education and Research U10.007, February 2010. Stockholm: The Ministry of Education and Research. 
Robertson, S. (2008). Europe/Asia Regionalism, Higher Education and the Production of World Order. Policy Futures in Education, 6(6): 718729.

Robinson, S., Mentrup, A., Barjak, F. \& Thelwall, M. (2007). Collection and Analysis of existing data on REsearchers CAReers (RESCAR) and implementation of new data collection activities - the Research team Survey, Final Report. Brussels: ERAWATCH Network.

Sporn, B. (2002). Building Adaptive Universities: Emerging Organisational Forms Based on Experiences of European and US Universities. Tertiary Education and Management, 7(2): 121-134.

Stretenova, N. (2003). Scientific mobility and 'brain drain' issues in the higher education sector in Bulgaria. CSLPE research report 2003-2. Leeds: University of Leeds.

Verbik, L. and Lasanowski, V. (2007). International Student Mobility: Patterns and Trends. London: The Observatory on Borderless Higher Education.

Winkler, G. (2007). Skills and Education - Is Europe on the Right Way? Österreichhischer National Bank 35. Volkswirtschaftliche Tagung 2007. Wien: ÖNB.

Wächter, B. (2004). The Bologna Process: developments and prospects. European Journal of Education, 39(3): 265-273.

Zgaga, P. (2007). Looking out: the Bologna process in a global setting. Oslo: Norwegian Ministry of Education and Research. 
To be published in:

Curaj, A.; Scott, P.; Vlasceanu, L.; Wilson, L. (Eds.) (2012). European Higher Education at the Crossroads. Between the Bologna Process and National Reforms. Dordrecht: Springer.

Annex 1: Students

\begin{tabular}{|c|c|c|c|c|c|c|c|c|c|c|c|c|}
\hline COUNTRY & \begin{tabular}{|l|} 
Foreign \\
students / \\
all students, \\
Tertiary \\
type A (\%) $^{1}$
\end{tabular} & \begin{tabular}{|l|} 
Percetage of \\
foreign / \\
internationa \\
I students \\
coming from \\
EU19 1,4
\end{tabular} & \begin{tabular}{|l|} 
Index of \\
change in \\
the number \\
of foreign \\
students, \\
2008 \\
$2000=100^{1}$ \\
\end{tabular} & \begin{tabular}{|l|}
$\begin{array}{l}\text { Share of } \\
\text { tuition fees } \\
\text { of university } \\
\text { revenues } \\
\text { (\%) in } 2008^{2}\end{array}$ \\
\end{tabular} & \begin{tabular}{|l|} 
Tuition fees \\
per annum \\
BA $(€)^{2}$
\end{tabular} & \begin{tabular}{|l|} 
Tuition fees \\
per annum \\
MA (€) ${ }^{2}$
\end{tabular} & \begin{tabular}{|l|} 
Small \\
freedom in \\
opening \\
progs \\
(accreditatio \\
n or other \\
restr.) \\
\end{tabular} & \begin{tabular}{|l|} 
Large \\
freedom in \\
opening \\
progs \\
(universities \\
may freely \\
open )
\end{tabular} & \begin{tabular}{|l|} 
Small \\
freedom to \\
set fees (no \\
fees, set by \\
external or \\
ceiling by \\
external)
\end{tabular} & \begin{tabular}{|l|} 
Large \\
freedom to \\
set fees \\
(free to set \\
fees or \\
cooperation) \\
3
\end{tabular} & \begin{tabular}{|l} 
Small \\
freedom in \\
student \\
intake (free \\
admission, \\
state \\
decides) \\
\end{tabular} & \begin{tabular}{|l} 
Large \\
freedom in \\
student \\
intake (uni \\
decides, split \\
system, \\
negot.)
\end{tabular} \\
\hline AT & 18.8 & 60.6 & 176 & 6 & 726 & 726 & $\mathrm{x}$ & & $\mathrm{x}$ & & $\mathrm{x}$ & \\
\hline $\mathrm{CY}$ & & & & 12 & 0 & 2500 & $x$ & & & $x$ & & $x$ \\
\hline$C Z$ & 7.5 & 73.4 & 510 & 5 & 0 & 0 & $x$ & & $x$ & & & $x$ \\
\hline DK & 7.6 & 30.1 & 149 & 2 & 0 & 0 & $x$ & & $x$ & & & $x$ \\
\hline EE & 3.6 & 64.7 & 281 & 13 & 0 & 0 & $x$ & & & $x$ & & $x$ \\
\hline $\mathrm{FI}$ & 3.3 & 20.3 & 203 & 0 & 0 & 0 & $x$ & & $x$ & & & $x$ \\
\hline$F R$ & 12.4 & 14.2 & 178 & 5 & 169 & 226 & $\mathrm{x}$ & & $\mathrm{x}$ & & $\mathrm{x}$ & \\
\hline DE & 12.2 & 22.3 & 131 & & $0-1000$ & $1-1000$ & $x$ & & $x$ & & & $x$ \\
\hline GR & 4.1 & 3.6 & 304 & & 0 & $1000-6000$ & $x$ & & & $x$ & $x$ & \\
\hline $\mathrm{HU}$ & 3.9 & 32.2 & 156 & 15 & 0 & 0 & $x$ & & & $x$ & & $x$ \\
\hline IS & 4.8 & 61.0 & 202 & 0 & 0 & 0 & $x$ & & $x$ & & & $x$ \\
\hline IE & $7.2^{5}$ & 26.7 & 173 & 35 & 0 & $3000-25000$ & & $x$ & $x$ & & & $x$ \\
\hline IT & 2.9 & 15.9 & 274 & 12 & $80-2600$ & $80-2600$ & $x$ & & $x$ & & $x$ & \\
\hline LV & & & & 15 & 1500 & 1500 & $x$ & & & $x$ & & $x$ \\
\hline LT & & & & 25 & 150 & 150 & $x$ & & & $x$ & $\mathrm{x}$ & \\
\hline LU & & & & 2 & 0 & 17500 & $x$ & & & $x$ & & $x$ \\
\hline $\mathrm{NL}$ & 6.9 & 51.6 & 291 & 6 & 1565 & 1565 & $x$ & & $x$ & & $x$ & \\
\hline NO & 7.1 & 29.2 & 185 & 0 & 0 & 0 & & $x$ & $\mathrm{x}$ & & $x$ & \\
\hline PL & 0.7 & 16.5 & 244 & 22 & 0 & 0 & $x$ & & & $x$ & & $\mathrm{x}$ \\
\hline PT & 4.7 & 16.8 & 175 & 10 & 700-900 & VARIABLE & $\mathrm{x}$ & & $x$ & & & $x$ \\
\hline ES & 2.4 & 16.9 & 255 & 21 & $600-1000$ & |1000-3000 & $x$ & & $x$ & & $\mathrm{x}$ & \\
\hline SK & 2.2 & 68.7 & 344 & 1 & 0 & 0 & $x$ & & $x$ & & & $x$ \\
\hline SE & 7.9 & 14.1 & 135 & 0 & 0 & 0 & & $x$ & $x$ & & & $x$ \\
\hline $\mathrm{CH}$ & 17.9 & 24.3 & 175 & 2 & $800-1300$ & $800-1300$ & & $x$ & $x$ & & $x$ & \\
\hline TR & 1.0 & 7.8 & 115 & 4 & $70-200$ & $100-300$ & $\mathrm{x}$ & & $x$ & & $x$ & \\
\hline UK & 20.8 & 28.1 & 151 & 24 & 3500 & $4000-8000$ & $x$ & & & $x$ & & $x$ \\
\hline
\end{tabular}

1 OECD 2010

2 Jongbloed et al. 2010

3 Estermann and Nokkala 2009

4 EU19: AT, BE, CZ, DK,FI, FR, DE, GR, HU, IE, IT, LU, NL, PL, PT, SK, ES, SE, UK.

5 Percentage of foreign students out of the tertiary education. 
Annex 2: Staff

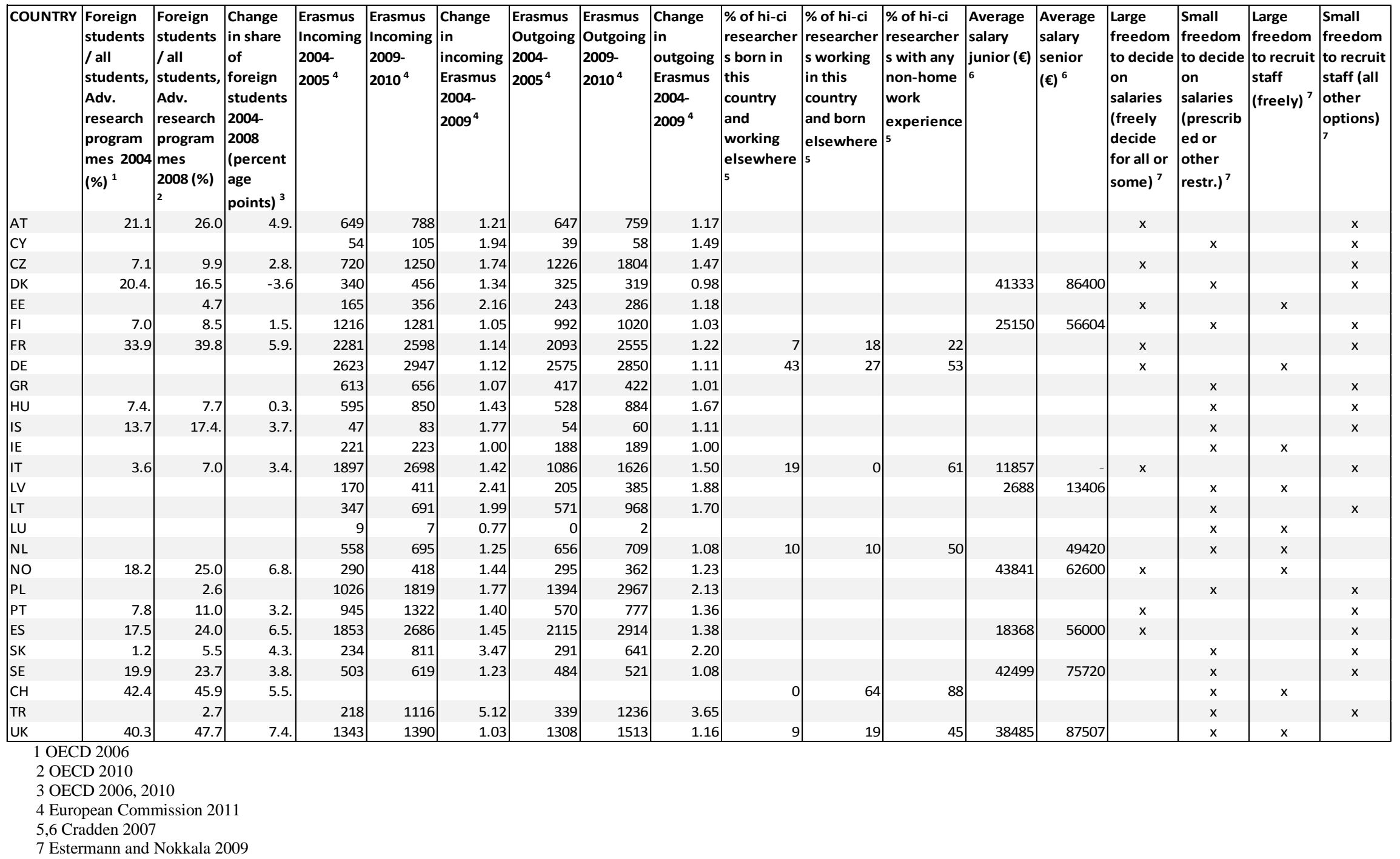

